\title{
PRAKTEK KERJA NYATA INTER PROFESSIONAL COLLABORATION (PKN-IPC) MAMPU MENINGKATKAN DERAJAT KESEHATAN MASYARAKAT
}

\author{
Warijan Warijan $^{*}$ 1) ; Marsum Marsum ${ }^{1)}$; Nina Indriyawati ${ }^{1)}$; Marichatul Jannah ${ }^{1)}$ \\ 1) Poltekkes Kemenkes Semarang \\ Jl. Tirto Agung ; Pedalangan ; Banyumanik; Semarang
}

\begin{abstract}
Abstrak
PKN IPC sebagai proses pembelajaran dilapangan bagi mahasiswa dikolaborasikan dalam berbagai disiplin ilmu direncanakan secara sistematis dan terpadu berdasarkan permasalahan yang digali dari keluarga dan dirumuskan bersama keluarga. Program PKN IPC dengan tema, Pemberdayaan Kesehatan dan Gizi Keluarga Berbasis Potensi Lokal yang diharapkan dapat meningkatkan empati, kepedulian, kerjasama mahasiswa dari berbagai latar belakang keilmuan dengan pendekatan kolaboratif untuk peningkatan kualitas hidup keluarga dan masyarakat dan mendorong terciptanya learning community. Program PKN-IPC sebagai bentuk pengabdian masyarakat dilaksanakan untuk membantu menyelesaikan persoalan pembangunan kesehatan di daerah secara kolaboratif. Kegiatan ini terlaksana pada tanggal 2-21 Juli 2018 di 16 desa Kecamatan Bringin dan 9 desa Kecamatan Bancak, Kabupaten Semarang. Peserta berjumlah 432 mahasiswa dari 5 Jurusan dan didampingi oleh 25 dosen pembimbing lapangan.
\end{abstract}

Kata kunci: derajat kesehatan; praktek kerja nyata ; inter professional collaboration

\begin{abstract}
[REAL WORK PRACTICE INTER PROFESSIONAL COLLABORATION (PKN-IPC) IS ABLE TO IMPROVE COMMUNITY HEALTH STATUS] PKN-IPC as a learning process in the field for students is collaborated in various disciplines planned systematically and integrated based on the problems that are explored from the family and formulated with family. PKN-IPC program with the theme, Local Potential-Based Family Health and Nutrition Empowerment which is expected to increase empathy, care, collaboration of students from various scientific backgrounds with a collaborative approach to improve the quality of family and community life and encourage the creation of learning communities. PKN-IPC program as a form of community service is carried out to help solve problems of health development in the region collaboratively. This activity was carried out on 2-21 July 2018 in 16 villages in Bringin Sub-district and 9 villages in Bancak Sub-district, Semarang District. There were 432 students from 5 majors and were accompanied by 25 field supervisors.
\end{abstract}

Keywords: health status ; real work practice ; inter professional collaboration

\section{Pendahuluan}

Praktek Kerja Nyata Inter Profesional Collaboration (PKN IPC) di Lingkungan Politeknik Kesehatan Kemenkes Semarang dilaksanakan pada tahun 2018 sebagai proses pembelajaran di lapangan bagi mahasiswa dalam mengkolaborasikan berbagai disiplin ilmu dan sekaligus sebagai wahana pemberdayaan

*) Warijan Warijan

E-mail: warijan.rmik@gmail.com kesehatan keluarga. Skema ini direncanakan dan dilaksanakan secara sistematis dan terpadu berdasarkan permasalahan yang digali dari keluarga, dirumuskan dan dilaksanakan bersama keluarga. Dari kegiatan ini diharapkan dapat memacu kemampuan keluarga dalam mengenali masalah, pengembangan diri dan lingkungannya sehingga kualitas hidup, kesehatan dan kesejahteraannya meningkat.

Program PKN IPC Poltekkes Kemenkes Semarang dengan tema "Pemberdayaan 
Kesehatan dan Gizi Keluarga Berbasis Potensi Lokal" merupakan bentuk perwujudan visi dan misi Poltekkes Kemenkes Semarang dalam menunjang Tri Dharma Perguruan Tinggi khususnya di bidang Pengabdian Masyarakat. Melalui Program ini diharapkan dapat meningkatkan empati, kepedulian, kerjasama mahasiswa dari berbagai latar belakang keilmuan dengan pendekatan kolaboratif untuk peningkatan kualitas hidup keluarga dan masyarakat serta mendorong terciptanya learning community.

Pelaksanaan Program ini sebagai bentuk pendidikan dengan cara memberikan pengalaman belajar kepada mahasiswa untuk hidup di tengah masyarakat di luar kampus. Bersama dengan masyarakat, mahasiswa secara langsung dapat mengidentifikasi serta menangani masalah kesehatan dan lingkungan yang terjadi. Kegiatan-kegiatan yang dilakukan untuk membantu menyelesaikan persoalan pembangunan kesehatan di daerah dilakukan secara kolaboratif dari berbagai jenis latar belakang pendidikan kesehatan.

Kegiatan PKN IPC ini diharapkan dapat menjadi kegiatan civitas akademika Poltekkes Kemenkes Semarang dalam membantu memberikan solusi terhadap permasalahan kesehatan masyarakat pedesaan dan dapat menjadi suatu kegiatan yang berkesinambungan dan berkelanjutan dalam pemberdayaan kesehatan masyarakat desa. Oleh karena itu, perlu ada suatu mekanisme pengaturan dan koordinasi kegiatan pengabdian masyarakat yang terstruktur dan berkesinambungan oleh institusi Poltekkes Kemenkes Semarang sehingga luaran dan dampak yang dihasilkan dapat lebih baik dan lebih dirasakan oleh masyarakat luas.

Berdasarkan latar belakang tersebut, keberadaan tenaga kesehatan serta pihak-pihak yang memiliki tanggung jawab untuk menggerakkan masyarakat dalam melakukan perubahan perilaku yang mendasari terbentuknya keluarga sehat berdasarkan indikator keluarga sehat di Kabupaten Semarang.

\section{Metode}

Tema kegiatan PKN-IPC yaitu pemberdayaan kesehatan dan gizi keluarga berbasis potensi lokal. Kegiatan ini terselenggara pada tanggal 2-21 Juli 2018 di Kabupaten
Semarang dengan rincian jadwal sebagai berikut :

Tabel 1. Jadwal Kegiatan PKN-IPC

\begin{tabular}{clc}
\hline No & \multicolumn{1}{c}{ Kegiatan } & $\begin{array}{c}\text { Durasi } \\
\text { Pelaksana } \\
\text { an }\end{array}$ \\
\hline 1 & Pembekalan DPL dan Mahasiswa & 1 hari \\
2 & Survey 12 Indikator Keluarga Sehat & 2 hari \\
3 & Analisis hasil survey dan identifikasi & 1 hari \\
& masalah & 1 hari \\
4 & Penyusunan rencana program & 1 hari \\
5 & Sosialisasi program & 1 hari \\
6 & Pelaksanaan program & 1 hari \\
7 & Evaluasi program & 21 hari \\
\hline & $\quad$ Total
\end{tabular}

PKN-IPC dilaksanakan di dua kecamatan di Kabupaten Semarang, yaitu Kecamatan Bancak dan Kecamatan Bringin.

Tabel 2. Mapping lokasi PKN-IPC

\begin{tabular}{lll}
\hline \multicolumn{1}{c}{ Kecamatan Bringin } & & Kecamatan Bancak \\
\hline 1. Desa Bringin & 1. & Desa Bancak \\
2. Desa Pakis & 2. & Desa Bantal \\
3. Desa Tempuran & 3. & Desa Boto \\
4. Desa Nyemoh & 4. & Desa Jlumpang \\
5. Desa Wiru & 5. & Desa Lembu \\
6. Desa Gogodalem & 6. & Desa Plumutan \\
7. Desa Kalikurmo & 7. & Desa Pucung \\
8. Desa Sambirejo & 8. & Desa Rejosari \\
9. Desa Kalijambe & 9. & Desa Wonokerto \\
10. Desa Tanjung & & \\
11. Desa Banding & & \\
12. Desa Truko & & \\
13. Desa Sendang & & \\
14. Desa Lebak & & \\
15. Desa Rembes & & \\
\hline 16. Desa Popongan & & \\
\hline
\end{tabular}

Setiap desa di tempati oleh 17-18 mahasiswa PKN-IPC yang terdiri dari berbagai Program Studi Sarjana Terapan yaitu Keperawatan Semarang dan Magelang, Kebidanan Semarang dan Magelang, Teknik Radiodiagnostik dan Radioterapi Semarang, Gizi, Keperawatan Gigi, Kesehatan Lingkungan.

Peserta adalah mahasiswa Program Sarjana Terapan Poltekkes Kemenkes Semarang yang telah menyelesaikan perkuliahan sekurang-kurangnya 100 SKS dengan IPK > 2 dan telah melakukan registrasi untuk mengikuti PKN-IPC ini. Mahasiswa yang telah memenuhi syarat tersebut dan berhak mengikuti PKN-IPC berjumlah 430 mahasiswa.

Narasumber yang terlibat dalam kegiatan 
ini meliputi Bupati Kabupaten Semarang, Camat Bancak dan Bringin, Kepala Puskesmas Bancak dan Bringin serta Motivator Entrepreneurship dari Kuncen Farm. Fasilitator merupakan panitia penyelenggara yang dibentuk dan ditetapkan melalui SK Direktur Poltekkes Kemenkes Semarang. Fasilitator berkoordinasi dengan Ketua Program Studi di setiap jurusan/prodi.

Kegiatan mahasiswa dilapangan akan di bimbing oleh Dosen Pembimbing Lapangan (DPL) yang ditetapkan melalui SK Direktur. Ada 25 DPL yang membimbing mahasiswa selama di desa yang tersebar di 25 Desa di 2 Kecamatan. Dosen Pembimbing Lapangan (DPL) merupakan dosen yang ditunjuk melalui SK Direktur untuk membimbing dan mengarahkan mahasiswa dalam pelaksanaan praktek PKN-IPC di lahan agar tujuan yang di inginkan dapat tercapai secara optimal.

Tahap pelaksanaan kegiatan diawali dengan survei data. Kegiatan ini dilakukan pada minggu pertama saat mahasiswa tinggal di desa. Survey dilaksanakan selama 2 hari dengan Instrumen Program Indonesia Sehat (PIS) Pendekatan Keluarga. Sampel dalam survey PKN-IPC adalah sebagian dari Populasi yg dihitung dengan pendekatan estimasi proporsi, berdasarkan angka keluarga tidak sehat di Kecamatan Gemawang sebesar 10,6\% (tahun 2016) dengan $\mathrm{d}=0.01$ dan design effect $=1$ diperoleh minimal sampel sebesar 3641. Dengan pertimbangan tertentu dalam survei ini diambil sampel sebesar 3680 yang tersebar di 25 desa. Setiap Desa diambil sampel sebanyak 140 -150 Rumah tangga.

Pengambilan sampel dilakukan secara multistage: Pada masing-masing desa, dari sejumlah RT yang ada dilakukan pengambilan sampel RT secara random sebanyak 15-16 RT. Kemudian dari listing sejumlah Keluarga yang ada di 15-16 RT tersebut dilakukan pengambilan sampel keluarga secara proporsional random sampling menurut RT. Hasil sampling PKN IPC tahun 2017 diperoleh sampel sebanyak 3680 rumah tangga, yang tersebar di 16 Desa pada Kecamatan Bringin dan 9 Desa pada Kecamatan Bancak. PKN-IPC tahun 2018 mempertimbangkan menggunakan data kohort, maka sampel PKN IPC tahun 2018 menggunakan sampel survei PKN IPC tahun 2017.

Analisis data dilakukan oleh mahasiswa di masing-masing desa untuk mempelajari dan menguji data dalam rangka untuk menetapkan masalah kesehatan. Analisis data dilakukan untuk menentukan kebutuhan kesehatan komunitas, kekuatan komunitas, pola respon kesehatan, kesehatan keluarga dan tren pemanfaatan pelayanan kesehatan. Langkah-langkah pengkajian sebagai berikut: 1) Mengkategorikan data; 2) Meringkas data per kategori; 3) Mengidentifikasi perbedaan data dan penghapusan data; 4) Membuat simpulan.

Program PKN-IPC yang terlaksana di Kabupaten Semarang terdiri dari program tematik, program non tematik dan program fakultatif. Rencana program dimusyawarahkan dengan segenap tokoh formal dan informal dalam Musyawarah Masyarakat Desa (MMD) dan kesepakatan tersebut dituangkan dalam dokumen komitmen pelaksanaan program peningkatan IKS. Berikut ini rincian program yang terlaksana di kecamatan Bancak dan Bringin:

Tabel 3. Program Tematik dan Non Tematik di Kecamatan Bancak dan Bringin, Kabupaten Semarang

\begin{tabular}{|c|c|}
\hline Program Tematik & Program Non Tematik \\
\hline $\begin{array}{l}\text { Advokasi peduli stunting } \\
\text { kepada para Kades dan } \\
\text { pejabat tingkat kecamatan }\end{array}$ & $\begin{array}{l}\text { Pembinaan peternakan } \\
\text { kambing }\end{array}$ \\
\hline $\begin{array}{l}\text { Expo pangan lokal untuk } \\
\text { mencegah stunting }\end{array}$ & Penyuluhan PHBS \\
\hline $\begin{array}{l}\text { Penyuluhan peduli stunting } \\
\text { pada remaja dan ibu hamil }\end{array}$ & Bimbingan belajar \\
\hline Penyuluhan bahaya merokok & $\begin{array}{l}\text { Partisipasi pengajian rutin tiap } \\
\text { dusun }\end{array}$ \\
\hline $\begin{array}{l}\text { Penyuluhan pemanfaatan } \\
\text { Jaminan Kesehatan Nasional } \\
(\text { JKN) }\end{array}$ & $\begin{array}{l}\text { Partisipasi kegiatan posyandu } \\
\text { tiap dusun }\end{array}$ \\
\hline $\begin{array}{l}\text { Penyuluhan } \quad \text { tentang } \\
\text { hipertensi }\end{array}$ & $\begin{array}{l}\text { Penyuluhan sampah organik } \\
\text { dan anorganik }\end{array}$ \\
\hline Revitalisasi posyandu lansia & $\begin{array}{l}\text { Penyuluhan cara menggosok } \\
\text { gigi yang benar }\end{array}$ \\
\hline Penyuluhan filtrasi air & $\begin{array}{l}\text { Presentasi produk MP-ASI } \\
\text { dan Finger Food }\end{array}$ \\
\hline Penyuluhan ASI Ekslusif & $\begin{array}{l}\text { Partisipasi mengajar mengaji } \\
\text { setiap hari setelah sholat } \\
\text { magrib }\end{array}$ \\
\hline Peyuluhan KB & Cek TTV \\
\hline $\begin{array}{l}\text { Gerakan stop generasi } \\
\text { merokok }\end{array}$ & Sholat subuh bersama \\
\hline Penyuluhan tentang TB & $\begin{array}{l}\text { Kegiatan jumat bersih dan } \\
\text { senam sehat }\end{array}$ \\
\hline \multirow[t]{3}{*}{$\begin{array}{l}\text { Penyuluhan pembuangan } \\
\text { limbah dan sampah }\end{array}$} & Posko Kesehatan \\
\hline & Pembuatan Taman Gizi \\
\hline & $\begin{array}{ll}\text { Penyuluhan } & \text { kesehatan } \\
\text { reproduksi } & \end{array}$ \\
\hline
\end{tabular}


Tabel 4. Program Fakultatif di Kecamatan Bancak dan Bringin, Kabupaten Semarang

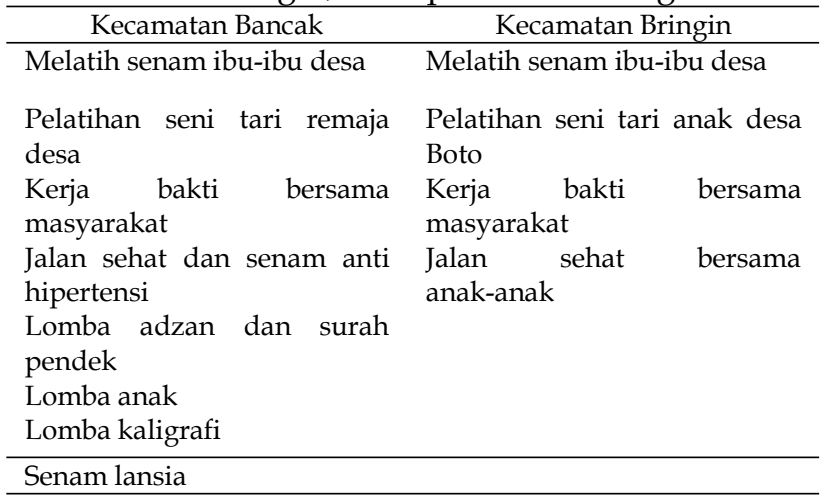

\section{Hasil dan Pembahasan}

Pendekatan keluarga telah dilaksanakan untuk mendukung tujuan Indonesia Sehat 2030. Ada beberapa daerah terpencil di kabupaten Semarang yang memiliki status kesehatan kurang. Poltekkes Kemenkes Semarang melakukan pendidikan antar profesi untuk penanganan masalah kesehatan dengan menggunakan strategi "one team one family". Tujuan dari penelitian ini adalah untuk mendeskripsikan status kesehatan keluarga dan menguraikan setiap indikator status.

Metode: Ukuran sampel ditentukan dengan teknik survei dengan multistage sampling. Keluarga yang dilibatkan dalam kegiatan ini sebesar 3680 keluarga dari daerah terpencil di kecamatan Bringin dan Bancak, Kabupaten Semarang. Status kesehatan keluarga dikategorikan menjadi tiga yaitu sehat, pra-sehat, dan tidak sehat dengan menggunakan 12 indikator keluarga sehat dari Kementerian Kesehatan.

Berikut ini hasil survei kategori keluarga sehat di kecamatan Bancak dan Bringin:

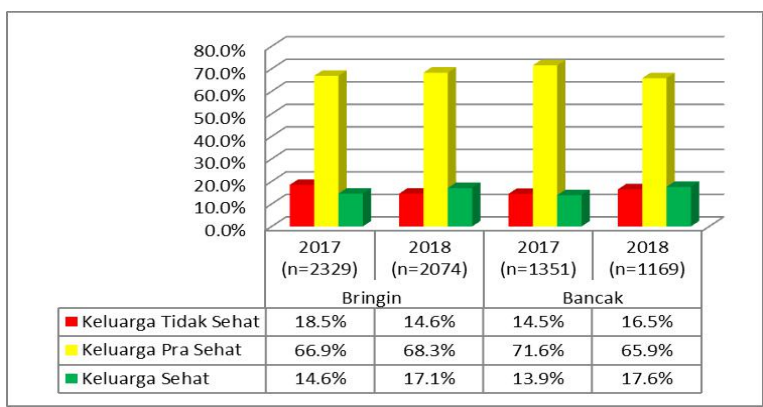

Gambar 1. Hasil Survey Kategori Keluarga Sehat di Kecamatan Bancak dan Bringin Tahun 2018
Hasil survey kategori keluarga sehat di Kecamatan Bancak tahun 2018 pada kategori keluarga tidak sehat $(16,5 \%)$; keluarga pra sehat $(65,9 \%)$; keluarga sehat (17,6\%). Kategori keluarga tidak sehat di Kecamatan Bringin $(14,6 \%)$; keluarga pra sehat $(68,3 \%)$; keluarga sehat $(17,1 \%)$.

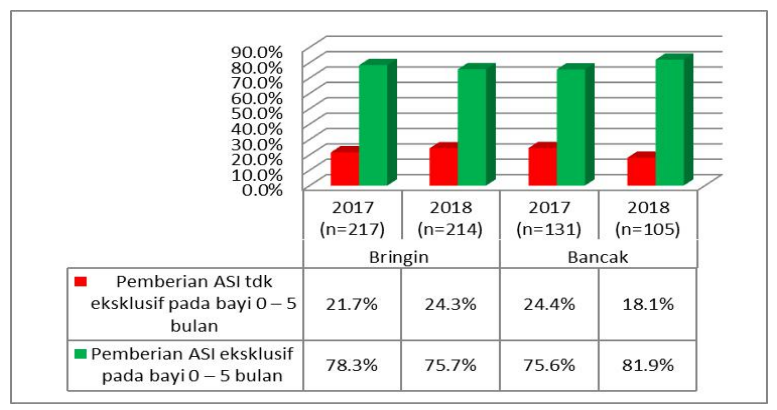

Gambar 2. Hasil Survey Keluarga Mengikuti Program KB (wanita menikah 10-54 \& tidak hamil/pria menikah $\geq 10$ tahun)

Hasil survey Keluarga yang Mengikuti Program KB di Kecamatan Bringin tahun 2018 (55,3\%); Kecamatan Bancak tahun 2018 (52\%). Sedangkan keluarga yang tidak mengikuti program KB di Kecamatan Bringin tahun 2018 (44,7\%); Kecamatan Bancak tahun 2018 (48\%).

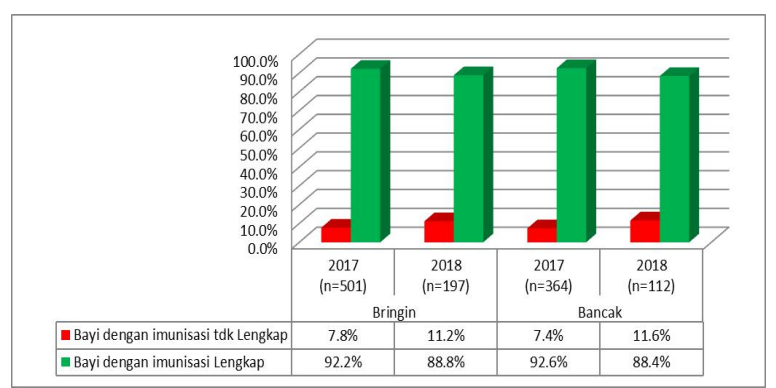

Gambar 3. Hasil Survey Bayi usia 0-11 bulan diberikan imunisasi lengkap: HB0, BCG, DPT-HB1, PT-HB2, DPT-HB3, Polio1, Polio2, Polio3, Polio4, Campak ( $A K$ berumur 12-23 bulan)

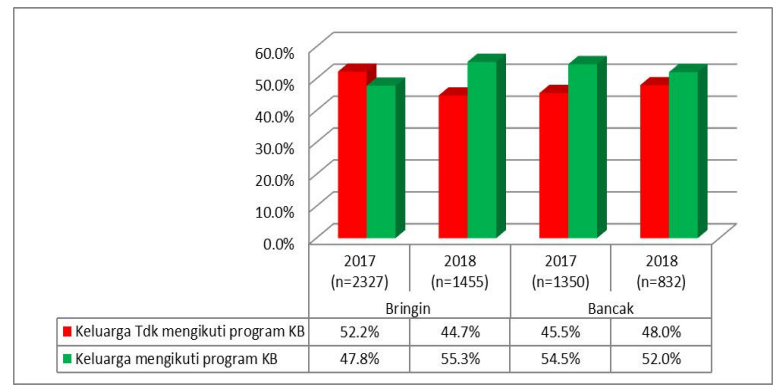

Gambar 4. Hasil Survey Pemberian ASI Ekslusif bayi 0-6 bulan (AK berumur 6-23 bulan) 


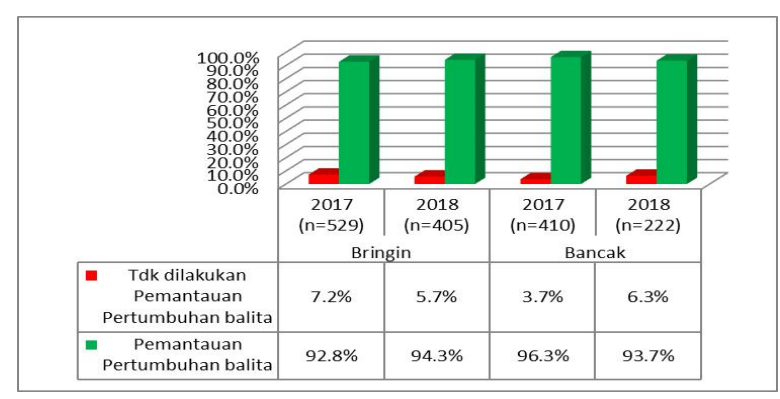

Gambar 5. Hasil Survey Pemantauan Pertumbuhan Balita (AK berumur 2-59 bulan

Hasil survey bayi dengan imunisasi lengkap: HB0, BCG, DPT-HB1, PT-HB2, DPT-HB3, Polio1, Polio2, Polio3, Polio4, Campak (AK berumur 12-23 bln) di Kecamatan Bringin tahun 2018 $(88,8 \%)$; bayi dengan imunisasi tidak lengkap $(11,2 \%)$. Sedangkan bayi dengan imunisasi lengkap di Kecamatan Bancak (88,4\%); bayi dengan imunisasi tidak lengkap di Kecamatan Bringin (11,6\%).

Hasil survey pemberian ASI Ekslusif bayi 0-6 bulan (AK berumur 6-23 bulan) di Kecamatan Bringin pada tahun 2018 (75,7\%); pemberian ASI tidak eksklusif pada bayi 0-6 bulan $(24,3 \%)$. Sedangkan pemberian ASI Eksklusif bayi 0-6 bulan di Kecamatan Bancak pada tahun 2018 (81,9\%); pemberian ASI tidak eksklusif pada bayi 0-6 bulan (18,1\%).

Hasil survey pemantauan pertumbuhan balita (AK berumur 2-59 bulan) di Kecamatan Bringin pada tahun 2018 (94,3\%); tidak dilakukan pemantauan pertumbuhan balita $(5,7 \%)$. Sedangkan pemantauan pertumbuhan balita di Kecamatan Bancak pada tahun 2018 $(93,7 \%)$; tidak dilakukan pemantauan pertumbuhan balita $(6,3 \%)$.

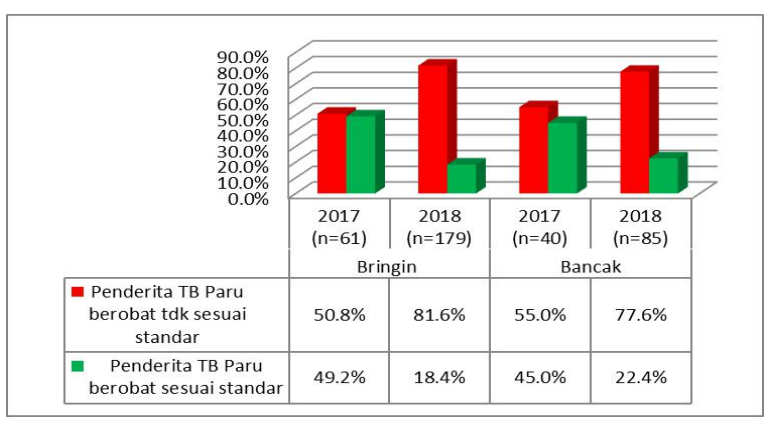

Gambar 6. Hasil Survey Penderita TB paru yang berobat sesuai standar selama 6 bulan (AK berumur $\geq$ 15 tahun)
Hasil survey pada penderita TB Paru yang berobat sesuai standar selama 6 bulan (AK berumur $\geq 15$ tahun) di Kecamatan Bringin pada tahun 2018 (18,4\%); penderita TB Paru yang berobat tidak sesuai standar $(81,65)$. Sedangkan penderita TB paru yang berobat sesuai standar di Kecamatan Bancak pada tahun 2018 (22,4\%); penderita TB Paru yang berobat tidak sesuai standar $(77,6)$.

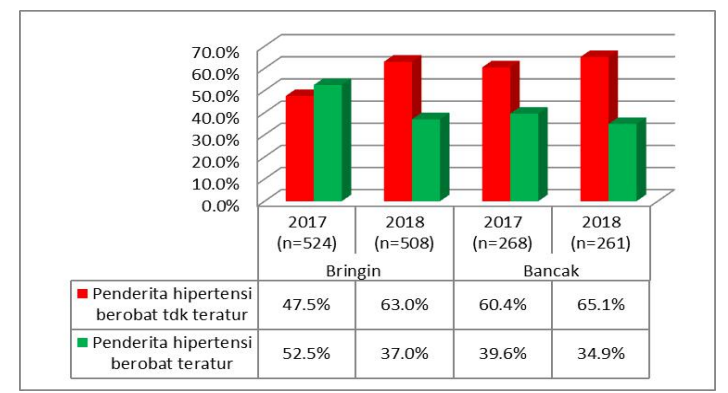

Gambar 7. Hasil Survey Penderita hipertensi yang berobat teratur (AK berumur $\geq 15$ tahun)

Hasil survey penderita hipertensi yang berobat teratur (AK berumur $\geq 15$ tahun) di Kecamatan Bringin pada tahun 2018 (37\%); penderita hipertensi yang berobat tidak teratur $(63 \%)$. Sedangkan penderita hipertensi yang berobat teratur di Kecamatan Bancak pada tahun 2018 (34,9\%); penderita hipertensi yang berobat tidak teratur $(65,1 \%)$.

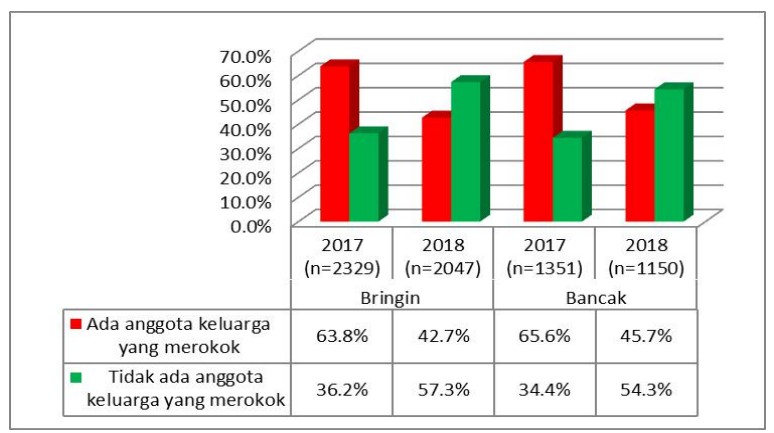

Gambar 8. Hasil Survey Ada anggota keluarga yang merokok (AK semua umur)

Hasil survey ada anggota keluarga yang merokok di Kecamatan Bringin pada tahun 2018 $(42,7 \%)$; tidak ada anggota keluarga yang merokok (57,3\%). Sedangkan ada anggota keluarga yang merokok di Kecamatan Bancak pada tahun $2018(45,7 \%)$; tidak ada anggota keluarga yang merokok $(54,3 \%)$. 


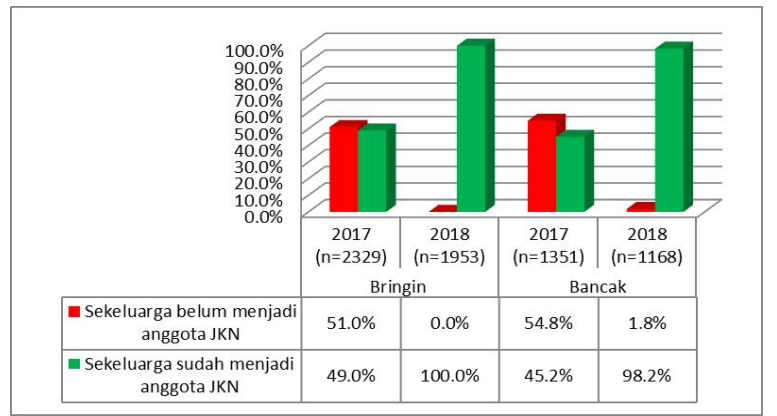

Gambar 9. Hasil survey sekeluarga sudah menjadi anggota JKN (AK semua umur)

Hasil survey sekeluarga yang sudah menjadi anggota JKN di Kecamatan Bringin pada tahun 2018 (100\%); Kecamatan Bancak $(98,2 \%)$.

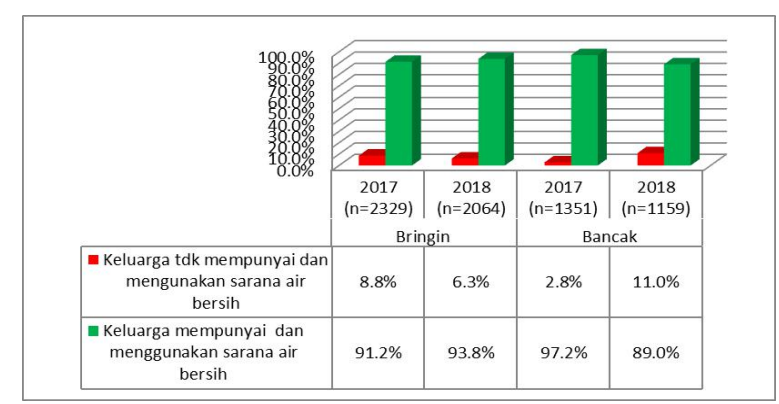

Gambar 10. Hasil survey keluarga mempunyai dan menggunakan sarana air bersih ( $A K$ berumur $\geq 15$ tahun)

Hasil survey Keluarga mempunyai dan menggunakan sarana air bersih (AK berumur $\geq 15$ tahun) di Kecamatan Bringin pada tahun 2018 (93,8\%); keluarga tidak mempunyai dan menggunakan sarana air bersih (6,35\%). Sedangkan keluarga mempunyai dan menggunakan sarana air bersih di Kecamatan Bancak pada tahun 2018 (89\%); keluarga tidak mempunyai dan menggunakan sarana air bersih $(11 \%)$.

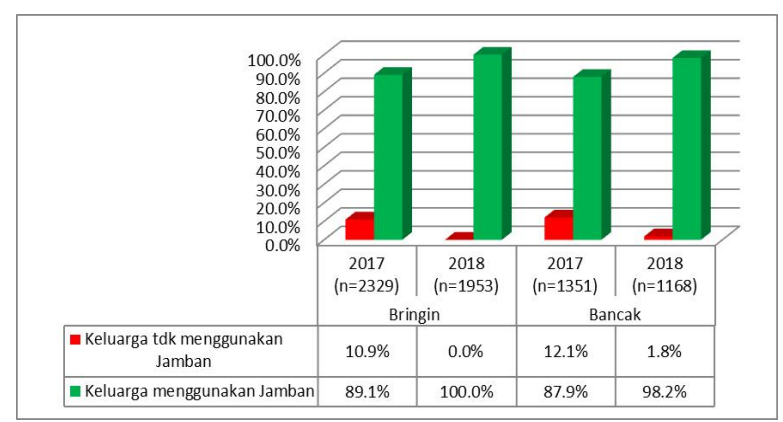

Gambar 11. Hasil Survey Menggunakan jamban keluarga ( $A K \geq$ berumur 15 tahun)
Hasil survey menggunakan jamban keluarga (AK $\geq$ berumur 15 th) di Kecamatan Bringin pada tahun 2018 (100\%); Kecamatan Bancak (98\%).

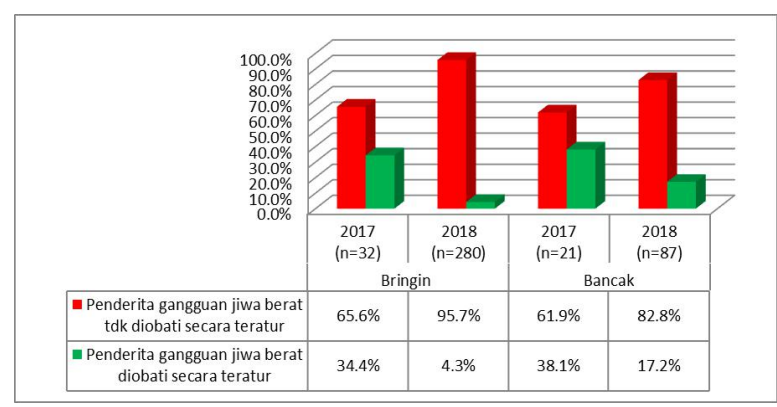

Gambar 12. Hasil survey ada penderita gangguan jiwa berat minum berobat secara teratur

(AK sетиа итиr)

Hasil survey ada penderita gangguan jiwa berat minum diobati secara teratur (AK semua umur) di Kecamatan Bringin pada tahun 2018 $(4,3 \%)$; penderita gangguna jiwa berat tidak diobati secara teratur (95,7\%). Sedangkan penderita gangguan jiwa berat minum diobati secara teratur di Kecamatan Bancak pada tahun 2018 (17,2\%); penderita gangguna jiwa berat tidak diobati secara teratur $(82,8 \%)$.

Berikut ini hasil survey proporsi stunting yang berada di Kecamatan Bancak dan Kecamatan Bringin, kabupaten Semarang beberapa tahun terakhir:

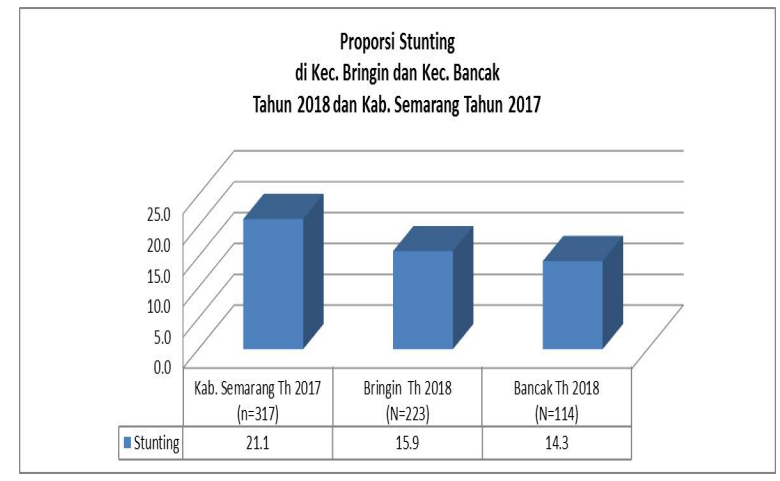

Gambar 13. Hasil Survey Proporsi Stunting di Kecamatan Bancak dan Bringin Tahun 2018 dan Kabupaten Semarang Tahun 2017

Hasil survey proporsi stunting di Kecamatan Bringin Tahun 2018 (15,9; N=223) sedangkan di Kecamatan Bancak (14,4; N=114). 


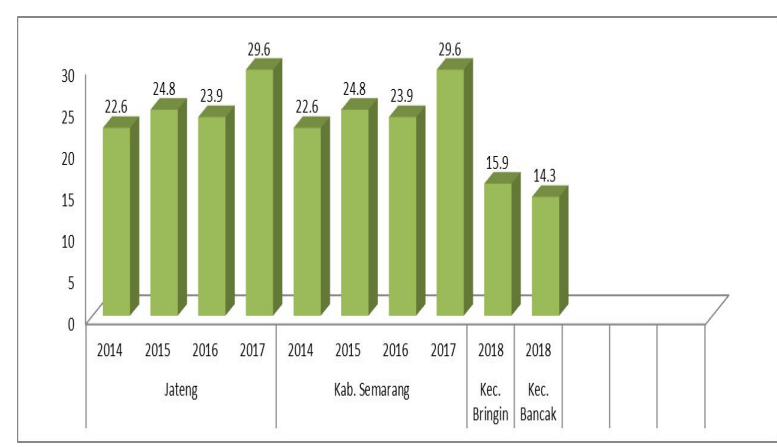

Gambar 14. Hasil Survey Kecenderungan Proporsi Stunting di Kabupaten Semarang Tahun 2014-2018

Hasil survey kecenderungan proporsi stunting di Kabupaten Semarang mengalami penurunan di tahun 2018, di Kecamatan Bringin $(15,9)$ dan Kecamatan Bancak $(14,3)$.

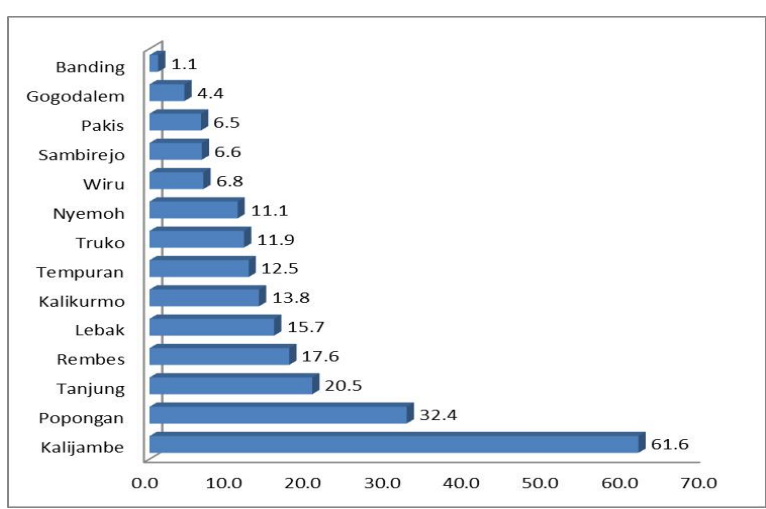

Gambar 15. Hasil Survey Proposal Stunting di Kecamatan Bringin Tahun 2018

Hasil survey proposal stunting di Kecamatan Bringin Tahun 2018 menunjukkan bahwa angka prevalensi tertinggi di Desa Kalijambe $(61,6 \%)$ sedangkan angka prevalensi terendah berada di Desa Banding (1,1\%).

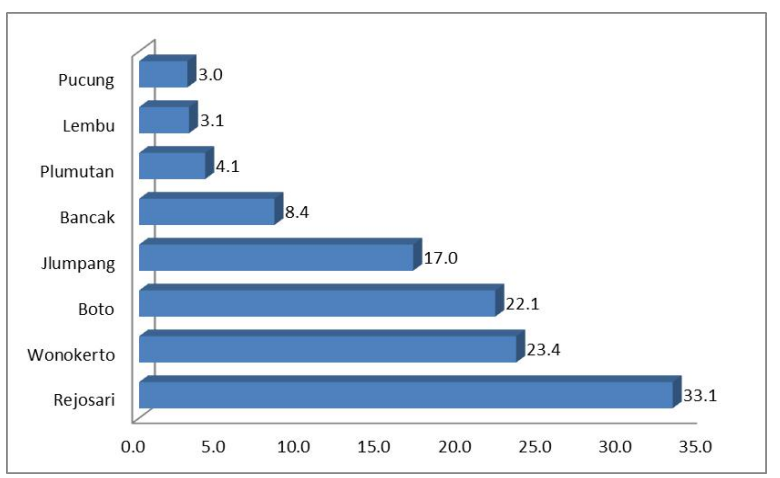

Gambar 16. Hasil Survey Proposal Stunting di Kecamatan Bancak Tahun 2018
Keterangan:

Data Desa Bantal, angka prevalensi stunting tidak dapat dihitung karena tidak memiliki data Tinggi Badan

Hasil survey proposal stunting di Kecamatan Bancak Tahun 2018 menunjukkan bahwa angka prevalensi tertinggi di Desa Rejosari $(33,1 \%)$ sedangkan angka prevalensi terendah berada di Desa Pucung (3\%).

\section{Simpulan dan Saran}

Program PKN IPC Poltekkes Kemenkes Semarang mengusung tema "Pemberdayaan Kesehatan dan Gizi Keluarga Berbasis Potensi Lokal" yang merupakan bentuk perwujudan visi dan misi Poltekkes Kemenkes Semarang dalam menunjang Tri Dharma Perguruan Tinggi-khususnya di bidang Pengabdian Masyarakat. Program tersebut mampu meningkatkan derajat kesehatan masyarakat di kecamatan Bancak dan Bringin, Kabupaten Semarang melalui upaya promotif dan preventif.

Dinas Kesehatan Kabupaten Semarang diharapkan dapat terus melakukan program peningkatan kesehatan yang mencakup 12 indikator keluarga sehat serta melakukan pemantauan untuk mencapai derajat kesehatan yang optimal. Poltekkes Kemenkes Semarang senantiasa untuk melakukan pengembangan dan menjaga keberlangsungan program dengan melakukan pengabmas wilayah atau desa binaan.

\section{Ucapan Terima Kasih}

Terima kasih disampaikan kepada DIPA Poltekkes Kemenkes Semarang yang telah mendanai keberlangsungan kegiatan ini. Terimakasih ditujukan pula kepada Bupati Kabupaten Semarang, Dinas Kesehatan Kabupaten Semarang, Kepala Puskesmas Bancak dan Bringin, Camat Bancak dan Bringin, Satuan Kerja Perangkat Daerah serta pihak lain yang terkait dalam keberhasilan kegiatan ini.

\section{Daftar Pustaka}

Barnsteiner, J.H., Disch, J.M., 2007. Promoting interprofesional education. Nursing outlook, 55 (3), pp.144-50. Available at: http://www.ncbi.nlm.nih.gov/pubmed/1 $\underline{7524902}$

Benedict, L., Robinson, K., Holder, C., 2006. Clinical Nurse Specialist Practice Within 
the Acute Care for Elders: Interdisciplinary Team Model. Clin Nurse Specialist.

Clamita M, Sedyowinarso M, Huriyati E, Wahyuningsih MS. 2012. Interprofesional.

Communication Guideline using principle of "Greet-Invite-Discuss"

CIHC. 2007. Interprofessional Education and Core Competencies, Literature Review. Canada. DeChurch, L.A., Mesmer-Magnus, J.R., 2010. The cognitive underpinnings of effectiveteamwork: ametaanalysis. Journal of Applied Pshycology 95 (1), 32-53

Hall, P., Weaver, L., 2001. Interdisciplinary Education Education and Teamwork: a Long and Winding Road.
Reeves, S., Lewin, S., Espin, S., Zwarenstein, M., \& Ed, H. B., 2011. Interprofessional Teamwork for Health and Social Care., pp. 32-33.

Wagner, J., Liston, B. \& Miller, J., 2011. Developing interprofessional communication skills. Teaching and Learning in Nursing, 6(3), pp.97-101. Available at: http://linkinghub.elsivier.com/retrieve/p ii/S1557308710001149 [Accessed March 25, 2012].

World Health Organization., 2010. Framework for Action on Interprofessional Education $\mathcal{E}$ Collaborative PracticeKaihatu, T.S. (2006, March). Good corporate governance dan penerapannya di Indonesia. Jurnal Manajemen dan Kewirausahaan, 8(1), 1-9. 